\title{
Late Quaternary Fluvial Sedimentation in the Voidomatis Basin, Epirus, Northwest Greece
}

\author{
JOHN LEWIN \\ Institute of Earth Studies, UCW, Aberystwyth, Llandinam Building, Penglais, Aberystwyth SY23 3DB, UK
}

MARK G. MACKLIN

Department of Geography, The University of Newcastle, Newcastle upon Tyne NEI 7RU, UK

AND

JAMIE C. WOODWARD

The Godwin Laboratory, Sub-department of Quaternary Research, University of Cambridge, Cambridge $C B 23 R S, U K$

Received October 17, 1989

\begin{abstract}
Detailed morpho- and lithostratigraphic investigations, allied with radiometric dating, in the Voidomatis basin, Epirus, northwest Greece, have identified four Quaternary terraced alluvial fills that range from middle Pleistocene to historic in age. Major periods of alluviation during the late Quaternary were associated with valley glaciation (ca. 26,000-20,000 yr B.P.) and subsequent deglaciation (ca. 20,000-15,000 yr B.P.) in the Pindus Mountains during Late Würmian times, and more recently linked to overgrazing sometime before the 11th century AD. The late Quaternary alluvial stratigraphy of the Voidomatis River is more complex than the "Older Fill" and "Younger Fill" model outlined previously, and it is suggested that these terms should no longer form the basis for defining alluvial stratigraphic units in the Mediterranean Basin. (1991 University of Washington.
\end{abstract}

\section{INTRODUCTION}

River systems in the Mediterranean region during Quaternary times, similar to many others in central and northern Europe (Starkel, 1985), appear to have responded in a sensitive manner to variations in sediment delivery rates to valley floors and also changes in hydroclimatological regimes. Episodes of alluviation in the Mediterranean have been attributed both to climatic controls (Bintliff, 1975, 1977), epitomized by Vita-Finzi's (1969) now-classic subdivision of valley sediment sequences in the region into "Younger Fill" and "Older Fill," and also anthropogenic influences (Davidson, 1980). Later workers (e.g., Gilbertson et al. 1983; Gomez, 1987; Pope and van Andel, 1984; Wagstaff, 1981), however, have questioned the applicability of Vita-Finzi's model to regionally diverse and stratigraph- ically complex alluvial chronologies, especially in those areas where tectonic activity has been important (Harvey and Wells, 1987).

A new examination of Palaeolithic sites in Epirus, northwest Greece by Bailey and his co-workers (Bailey et al. 1983, 1984, 1986), provided an ideal field setting in which to use modern geomorphological and sedimentological techniques to examine Quaternary alluvial environments in a key area for European Palaeolithic studies. Investigations have centered on the Voidomatis basin (Fig. 1), and in particular on a $15.8-\mathrm{km}$ reach of the Vikos gorge. This limestone gorge effectively forms a single Palaeolithic site complex that includes four natural rockshelters all of which contain Upper Palaeolithic industries. The most notable of these is Klithi; discovered in 1979 . it is the largest and richest rockshelter site 
known in Epirus, with archaeological deposits radiometrically dated from between 17,000 and 10,000 yr B.P. (Bailey et al., 1986).

Quaternary alluvial and colluvial sediments are well exposed both on the sides and floor of the Vikos gorge and, in conjunction with archaeological material, provide the basis for palaeoenvironmental reconstruction. The aim of the study reported here was to establish the sequence, depositional environments, and ages of Quaternary alluvial, colluvial, and glacial units in the Voidomatis basin. Viewed in a wider context, the late Quaternary alluvial history of the Voidomatis is probably somewhat atypical of many other river basins hitherto investigated in the eastern Mediterranean by virtue of its mountain headwaters which supported glaciers in Würmian times, and probably during earlier Pleistocene glaciations. Its Quaternary sedimentary sequence and Palaeolithic archaeological record may therefore be usefully compared and contrasted with those of lowland and nonglaciated upland catchments in Greece and elsewhere in the Mediterranean. An additional approach used in our work has been detailed lithological analyses of both coarseand fine-grained alluvial units. This has enabled us both to construct lithostratigraphic sequences and, perhaps more important, to relate these to differentially operating sediment sources in the late Quaternary.

\section{PHYSIOGRAPHY AND GEOLOGY OF THE VOIDOMATIS BASIN}

The Voidomatis River upstream of its confluence with the Aoos River drains an area of $384 \mathrm{~km}^{2}$ (Fig. 1). It is a gravel-bed river of steep gradient, $\left(0.016 \mathrm{~m} \mathrm{~m}^{-1}\right)$ reflecting the high relief $(>2000 \mathrm{~m})$ of its catchment; it flows in a generally northwesterly direction, draining part of the western flank of the Pindus Mountains. In summer and early autumn, strcamflow is maintained only in the lower reaches of the Voidomatis by a major spring resurgence near Vikos. Runoff in the middle and head- water parts of the catchment is generated by winter rains and snowmelt during the spring.

Five physiographic units, distinguished on the basis of geology and topography, can be recognized in the Voidomatis basin. The first unit is a mountainous limestone region in the eastern and northeastern part of the catchment close to the village of Tsepelovon (Fig. 1). Here, little-modified glacial landforms (cirques, U-shaped valleys, lateral and end moraines, kame terraces) are well developed, and extensive glacially related sediments (tills, glaciofluvial deposits) indicate recent glaciation.

Second, a heavily dissected flysch basin (of Miocene age) lies upstream of Kipi (Fig. 1); this was beyond the limits of recent glaciation in the catchment and displays many of the classic "badland" slope forms typical of the semiarid regions of the western United States and found extensively on certain lithologies in the Mediterranean.

The third subregion is the upper Vikos gorge (between Monodendrion and Vikos; Fig. 1). The gorge, judged to be one of the most spectacular in the Balkans, is cut in Focene and Jurassic limestone and has near vertical sides up to $800 \mathrm{~m}$ high. Talus cones (>40 $\mathrm{m}$ thick) and aprons mantle the walls of the gorge and locally cover or interdigitate with coarse-grained alluvial sediments ( $>20 \mathrm{~m}$ thick) that underlie the gorge floor.

The fourth physiographic unit is the lower Vikos gorge that contains the majority of the Palaeolithic sites. This is separated from the upper part of the Vikos gorge at a point, $2 \mathrm{~km}$ southeast of Papingon (Fig. 1), where the Voidomatis leaves the confines of the Gamila Massif. It extends downstream as far as Old Klithonia bridge where its narrow limestone walls (up to 150 $m$ high) open out onto the Konitsa basin. Alluvial fans are well developed at the mouths of a number of tributary streams in the lower gorge that drain areas of flysch bedrock (e.g., $2 \mathrm{~km}$ northeast of Aristi; Fig. 1), which crops out on the upper slopes of a considerable part of the lower Vikos gorge. 


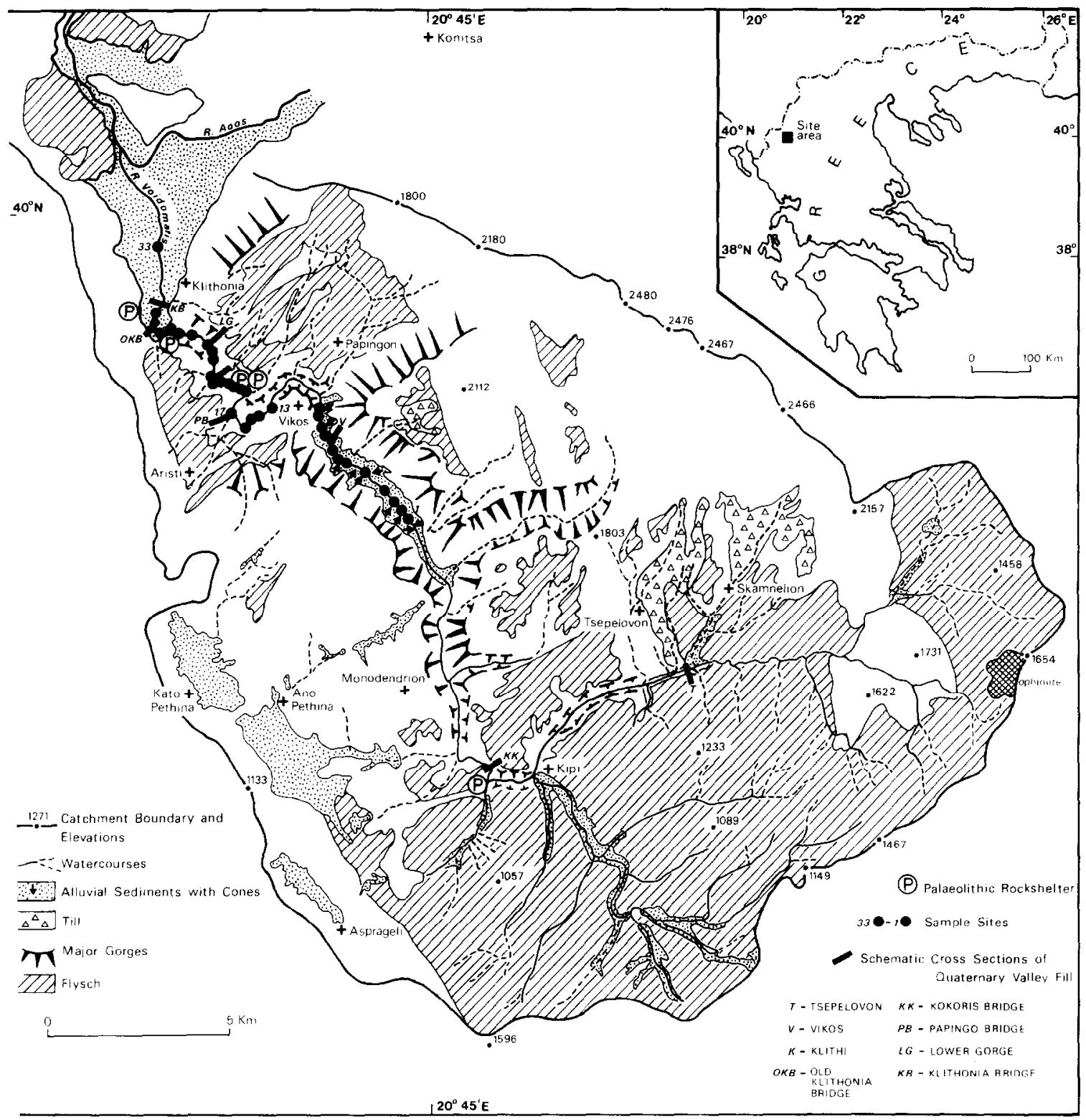

FIG. 1. Map of Voidomatis basin, showing its drainage network, geology, location of Palaeolithic rockshelters, and study and sample sites. Those parts of the basin that are not shaded are underlain by Eocene and Jurassic limestone. Altitudes are in meters.

Where the floor of the gorge widens, dissected colluvial sediments ( $>15 \mathrm{~m}$ thick) and terraced alluvial deposits ( $>25 \mathrm{~m}$ thick) are well preserved.

The fifth physiographic unit is the Konitsa basin. This is a fault-controlled graben of Tertiary age into which the Voidomatis and Aoos Rivers flow. The ac- tive channel and floodplain of the Voidomatis here is rarely more than $200 \mathrm{~m}$ wide and recent sediments are flanked by extensive Quaternary alluvial deposits whose surfaces lie between 5 and $10 \mathrm{~m}$ above river bed level.

These five physiographic units have provided sources for the river sediments which 
have operated differentially over time, and they also have supplied material whose characteristics are diagnostic of source area. Headwater subbasins may be underlain either by a single rock type (e.g., flysch basin upstream of Kipi, limestone in the upper Vikos gorge and Tsepelovon district), or they incorporate a small area of petrographically distinctive bedrock (e.g., ophiolite complex in the most eastern corner of the catchment), or contain localized glacigenic deposits. Thus, we have found that analysis of the lithological composition of Quaternary alluvial deposits in the middle and lower reaches of the Voidomatis has allowed sediment sources to be readily identified.

\section{METHODS OF INVESTIGATION}

Morphostratigraphic relationships between Quaternary alluvial, colluvial, and glacial fills in the Voidomatis basin were established by extensive field reconnaissance and detailed morphological mapping. In addition, at 33 sites in the Vikos gorge (downstream of a point $5 \mathrm{~km}$ north of Monodendrion) and Konitsa basin (upstream of a point $1 \mathrm{~km}$ northeast of Klithonia; Fig. 1) an aneroid barometer was used to measure the height of river terraces and fans (to the nearest $0.3 \mathrm{~m}$ ) above a fixed local datum. At eight locations along the Voidomatis (shown and listed in Fig. 1), exceptionally good exposures of valley fill sediments (mostly in currently eroding river bank sections) allowed detailed examination of Quaternary deposits in all of the five major physiographic units. At these sites the sedimentary properties, sequence, and architectures of all Quaternary units were carefully recorded. Sediment logs from a further 32 sites, at which sections were rather less laterally or vertically extensive, were used to supplement and, in places, refine lithostatigraphic rclationships.

Lithological and mineralogical analyses of both the gravel $(8-256 \mathrm{~mm})$ and silt and clay sediment $(<0.063 \mathrm{~mm})$ fractions were carried out on a range of Quaternary fluvial and glacial deposits in the Voidomatis ba$\sin$. The mineral composition of 14 bedrock samples and 36 samples of fine-grained sediment that frequently forms a matrix in coarse-grained Quaternary deposits have been examined using XRD techniques. Although estimates of mineral abundance obtained by this method are no more than relative and semiquantitative they do provide an extremely useful means for comparing intersample composition. The lithologies of 21 gravel-size sediment samples (including present-day river bed material and all Quaternary alluvial units hitherto identified in the study area) have also been analyzed. Field procedure for analyzing gravel lithologies consisted of marking out a $1-\mathrm{m}^{2}$ square on the section to be sampled, removing all clasts exposed on the surface, and then establishing their size over the range $8-256 \mathrm{~mm}$ using templates graduated at $0.5 \phi$ intervals. The weight and number of clasts in each size fraction were counted and all were assigned to one of four predetermined lithological classes: limestone, flysch, flint, or igneous rock types. This entailed hand sieving 4.75 tons of gravel and measuring 16,263 clasts.

Quaternary deposits in the Voidomatis basin have been dated by a range of radiometric dating techniques $\left({ }^{14} \mathrm{C}, \mathrm{TL}, \mathrm{ESR}\right)$. Organic material (plant macrofossils and charcoal) associated with river terraces, ranging in age from historical to Late Würmian, has been ${ }^{14} \mathrm{C}$ dated at two sites in the Konitsa basin (Old Klithonia bridge, Klithonia bridge; Fig. 1) and at one site in the lower Vikos gorge (Klithi; Fig. 1) using small sample ${ }^{14} \mathrm{C}$ AMS techniques. Age control is also provided by three TL sediment dates and three ESR dates from a deer tooth incorporated within a Pleistocene alluvial deposit at Old Klithonia bridge.

\section{QUATERNARY ALLUVIAL SEQUENCE IN THE VOIDOMATIS BASIN}

Four Quaternary alluvial units that predate the contemporary floodplain have been identified in the Voidomatis basin. 
Their sedimentary properties, height relationships, depositional environments, and ages are summarized in Table 1. The names used for all alluvial units are informal and they are described below in order of age.

\section{Kipi Unit}

This is the oldest alluvial fill yet identified in the study basin. It has been recognized only at one site near Kokoris bridge ( $1.5 \mathrm{~km}$ west of Kipi; Figs. 1 and 2$)$ in a road cutting where $22.9 \mathrm{~m}$ of the unit was exposed. The Kipi alluvial fill comprises flatbedded, imbricated sandy gravels that grade down valley into reddish crossstratified sands. The contact between vertically contiguous gravel units is generally nonerosional and frequently marked by thin beds $(<0.2 \mathrm{~m})$ of laminated silts. Coarser sediments within the Kipi unit are interpreted as longitudinal/midchannel barforms deposited in an aggrading, lowsinuosity river system, with sands and silts representing bar-tail fines and bar-surface drapes, respectively. The surface of the Kipi terrace lies $56 \mathrm{~m}$ above present river bed level; it is underlain by Miocene flysch and was deposited before the formation of the small limestone gorge in which the Voidomatis now flows at that point. High proportions of igneous and flysch rock types and low amounts of limestone (Table 1 and Fig. 3) distinguishes the Kipi unit from other Quaternary alluvial fills in the Voidomatis basin and suggests higher rates of coarse sediment delivery from the easternmost parts of the catchment (where ophiolite rock types crop out) than at present. A TL date of $>150,000 \mathrm{yr}$ B.P. (VOI26) was obtained from silts close to the base of the section and gives a minimum age for the deposition of the Kipi unit. The deposit is highly weathered and we believe that it may correlate with some of the "red beds" described elsewhere in the Mediterranean.

\section{Aristi Unit}

The Aristi unit is the major alluvial fill in the catchment and can be traced almostly continuously from till at the Tsepelovon moraine complex (Figs. 1 and 2) to the present Aoos-Voidomatis junction in the Konitsa basin more than $30 \mathrm{~km}$ downstream. It forms a prominent terrace (Fig. 4) with an average height of $12.4 \mathrm{~m}$ above river bed level. The Aristi unit ranges up to at least $25.9 \mathrm{~m}$ thick and consists almost entirely of flat-bedded or massive, matrixrich cobble gravels with occasional boulder-sized clasts. Imbrication between clasts is locally well developed where there is a lower proportion of whitish-gray silty matrix. XRD analysis of the $<63 \mu \mathrm{m}$ size fraction in the Aristi unit (Fig. 5) showed a mineralogical composition very similar to till at Tsepelovon from which it appears to have been partly derived. It has a large proportion of limestone-derived (calcite-rich) siltsize sediment, composed of hard, finegrained carbonates, which appears to have been liberated in significant amounts by physical communition in a glacial environment. The gravel-size fraction of the Aristi alluvial fill also is lithologically similar to the till, containing up to $95 \%$ limestone and significant amounts of flint (Fig. 3).

The Aristi unit is believed to be the terraced remnant of a formerly extensive glaciofluvial outwash train that was deposited by an aggrading, low-sinuosity proglacial stream which drained a series of valley glaciers in the Tsepelovon region. In common with many contemporary and Pleistocene glacially fed river systems, suspended sediment loads of the Voidomatis were high during this period, as shown by the large proportion of silt- and sand-size matrix in the Aristi gravels. The combination of high suspended sediment loads during Aristi times, and temporary ponding of tributary streams by the Voidomatis during major floods, resulted in the deposition of several meters of fine-grained slack-water sediment (cf. Baker et al., 1983) at a number of tributary/main valley junctions (e.g., Papingo bridge and Old Klithonia bridge; Figs. 1 and 2). Toward the base of gravels underlying slack-water sediments at Old Klithonia bridge, part of a Red Deer jawbone and a 


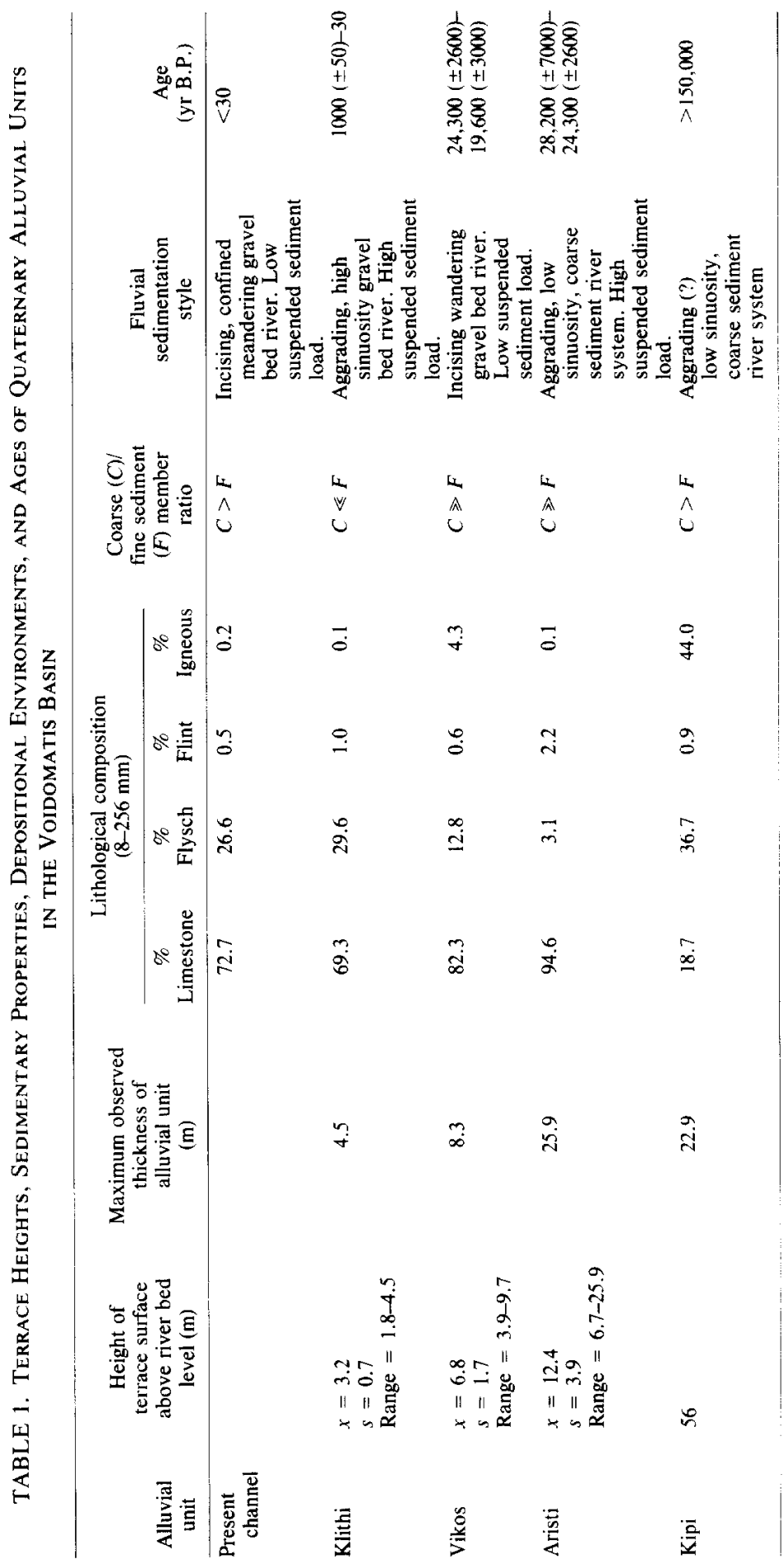




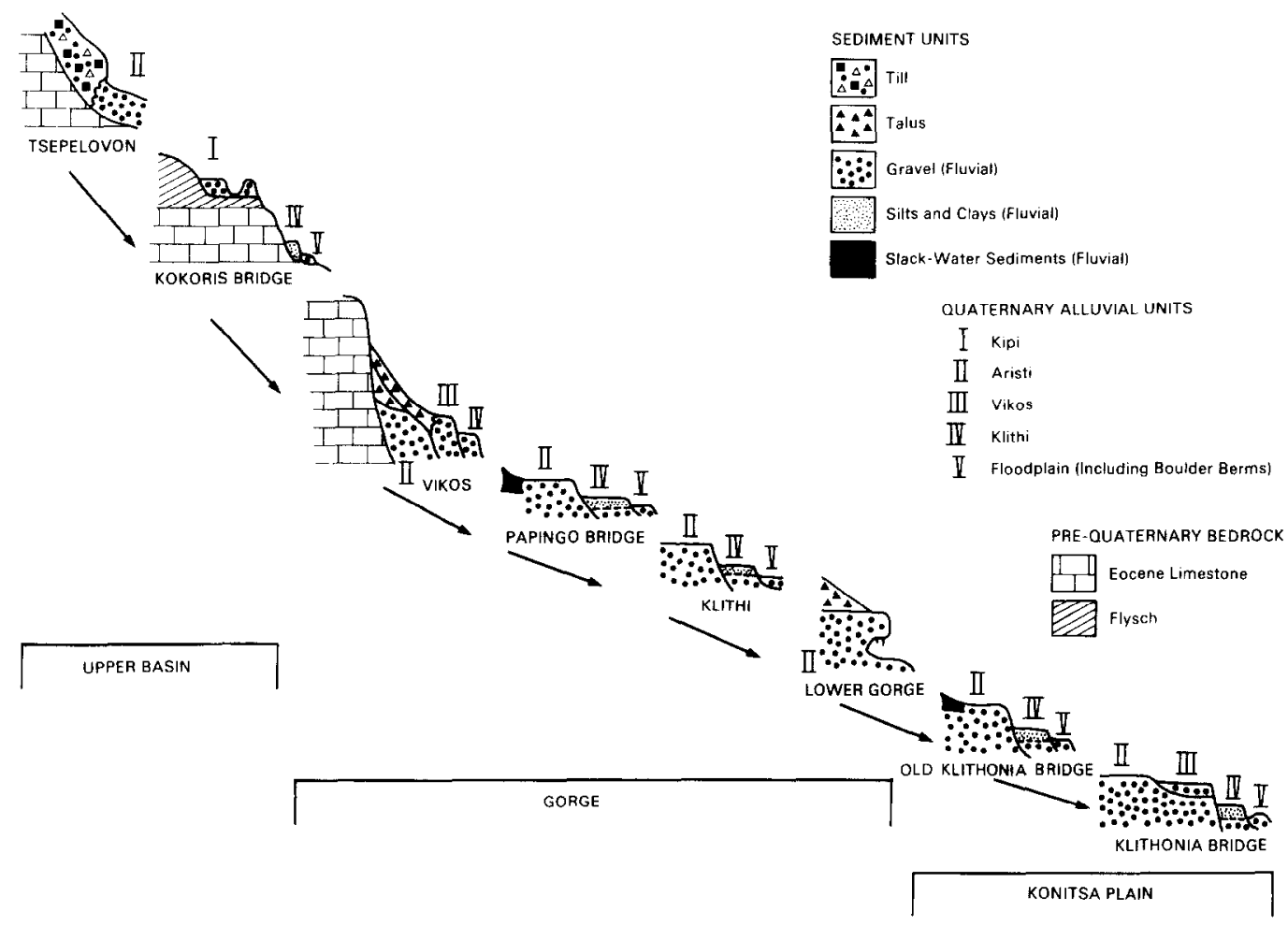

FIG. 2. Quaternary valley fill sequence in the Voidomatis basin. Locations of schematic cross sections are shown on Fig. 1.

number of flint flakes were recovered from silty, sandy fill of a small channel. The fragility of the bone and unmodified condition of the artifacts suggests that they had not been moved any great distance. A tooth from the deer mandible was dated by ESR (using the linear, continuous U-uptake model; R. Grün, per. comm., 1989) and gave ages of $24,300 \pm 2600$ (571c), 25,000 \pm 500 (57la), and 26,000 \pm 1900 (57lb) yr B.P. from three separate dating assays. These ages, together with a TL date of $28,000 \pm 7100$ yr B.P. (VOI23) from sediments at Old Klithonia bridge, indicate that the Aristi unit, and the glaciation to which it relates, is of Late Würmian age. They also show that deposition of the unit was at least partly contemporaneous with early Upper Palaeolithic human activity in the lower Vikos gorge and Konitsa basin.

\section{Vikos Unit}

The Vikos unit is a relatively minor but lithologically and sedimentologically distinctive alluvial fill. Its terrace surface lies between 3.9 and $9.7 \mathrm{~m}$ above river-bed level and the unit has a maximum thickness of $8.3 \mathrm{~m}$. The fill consists of contactimbricated brownish sandy gravels with a significantly lower matrix content than alluvium of the Aristi terrace. Large-scale erosional channel forms (with comparatively low W/D ratios), which are generally absent in the Kipi and Aristi gravels, are well developed in the Vikos unit and suggest that the Voidomatis, at this time, was incising its channel. Fine-grained sediment fill in a channel in the upper part of the Vikos unit at sample site 13 (Fig. 1; $1 \mathrm{~km}$ west of Vikos) has been dated by TL to $19,600 \pm 3000$ yr B.P. (VOI24). This establishes a minimum age for the deposition of this alluvial fill. Although the Vikos terrace cannot be traced upstream into glacial deposits, the predominance of limestone in its gravel-size fraction (Fig. 3) (considerably 

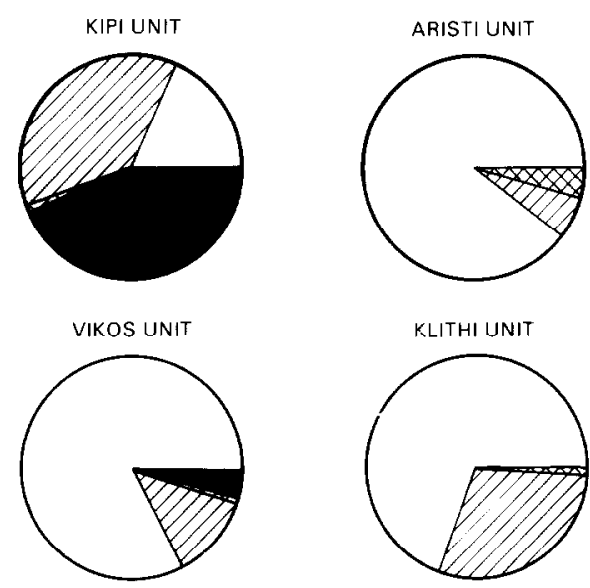

CONTEMPORARY RIVER
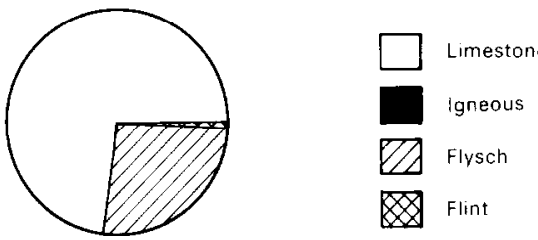

FIG. 3. Pie charts showing lithological composition of gravel in Voidomatis Quaternary alluvial units.

higher than that in younger alluvial units), together with the mineralogically intermediate character of its fine-grained matrix (Fig. 5), indicates that it represents a period during which there was substantial reworking of previously emplaced glacial sediment. Therefore, the Vikos unit was likely formed during a Late Würmian deglacial phase, sometime after 24,300 but before 16,600 yr B.P. However, high percentages of igneous rock types in the coarsesediment fraction (Fig. 3), and a comparatively high proportion of flysch-derived fines in the matrix (Fig. 5), also indicate a significant episode of erosion in those parts of the Voidomatis basin not underlain by limestone.

\section{Klithi Unit}

The Klithi unit underlies a terrace ca. $3 \mathrm{~m}$ above river bed level (Fig. 4) and represents the most important evidence for an episode of valley floor alluviation of demonstrable Holocene age in the Voidomatis catchment. It has many of the sedimentary characteristics of alluvial deposits that have been described in many parts of the Mediterranean Basin by Vita-Finzi (1975) and subsequent workers (Wagstaff, 1981) as "Younger Fill."

The Klithi unit is composed of two distinct lithofacies: a thick (up to $2.5 \mathrm{~m}$ ) upper unit of crudely bedded buff sandy silts which fine upward, that overlie flatbedded, contact-imbricated sandy gravels. This coarse/fine couplet with upward fining is a "type" example of a sedimentary sequence produced by lateral migration and associated sedimentation in a high sinuosity meandering river (Jackson, 1978). The sandy silts are interpreted as overbank fines and the sandy gravels as withinchannel sediments resulting from river bed/ bar accretion. The Klithi unit appears to have been deposited by an aggrading, meandering river system with suspended sediment concentrations in flood waters significantly higher than those of the present day.

Comparatively low rates of lateral channel movement during this period allowed the development and subsequent preservation of thick sequences of vertically accreted fine sediment. The fine-grained lithofacies of the Klithi unit attains its maximum thickness in the lower Vikos gorge where mineralogical analyses (XRD) show that it has been derived from erosion of local Miocene flysch (Fig. 5). Clast lithological analyses also showed the Klithi fill to have a high proportion of flysch rock types in its gravel size fraction (Fig. 3). Flysch crops out extensively in this part of the basin and is dissected by numerous gully systems (many of which are now partially stabilized by vegetation) that feed directly into the Voidomatis.

Sheets of colluvium consisting entirely of flysch lithologies mantle many parts of the lower Vikos gorge and slopes surrounding the Konitsa basin. When seen in section at the margins of the valley floor, colluvial sediment frequently interdigitates with the fine member of the Klithi unit. Charcoal recovered from the upper part of a sequence 


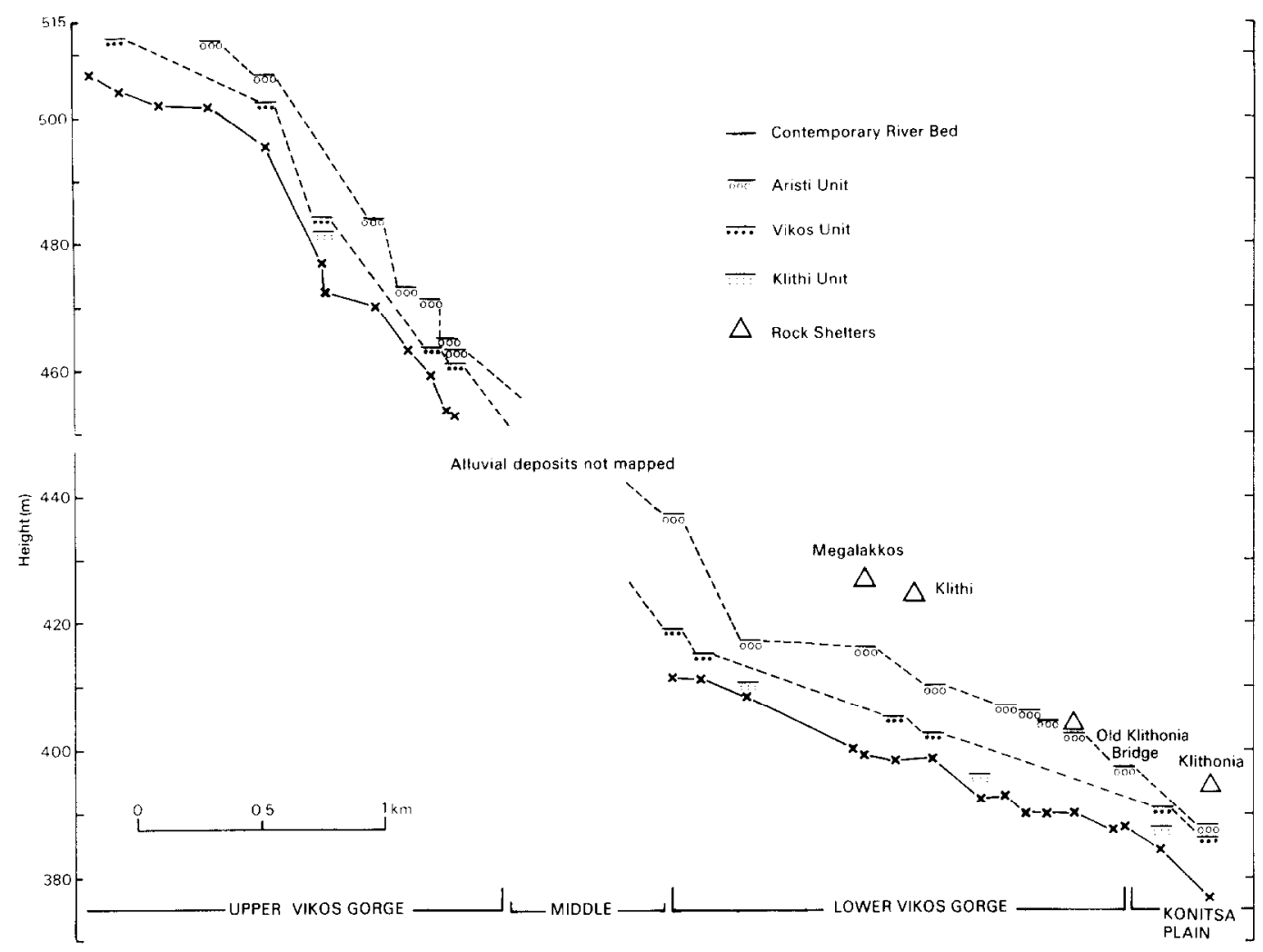

FIG. 4. Quaternary alluvial terraces in the Vikos gorge and Konitsa plain. The heights of rockshelters above present river bed level are also shown.

of colluvial sediments $200 \mathrm{~m}$ below the road bridge at Klithonia (Fig. 1) has been dated to between $800 \pm 100$ (OxA-192) and 1000 $\pm 50(\mathrm{OxA}-191)$ yr B.P. and suggests that this major period of hillside erosion and coeval deposition of the Klithi alluvial fill ended shortly after 1150 AD. Near Klithi (Fig. 1), however, organic deposits ${ }^{14} \mathrm{C}$ dated as modern (OxA-1747) underlie more than $2 \mathrm{~m}$ of flysch-derived alluvial and colluvial sediments, and indicate the continued development, at least locally, of the Klithi unit until quite recent times. Erosion here is believed to have been caused by intense grazing of flysch slopes shortly after World War II up until the early 1960s.

There is a close similarity between the thick sequences of overbank fines and colluvium that characterize the Klithi unit and the widespread "haugh loams" of central and northwest Europe (Butzer, 1980;
Macklin and Lewin, 1986) and "postsettlement alluvium" of North America (Knox, 1977), which formed in response to anthropogenically related deforestation and the advent of agricultural practice. Deposition of the Klithi unit also followed human disturbance of vegetation in the catchment on the readily erodible soils of flysch terrains during historical times.

\section{GLACIATION AND LATE QUATERNARY RIVER ENVIRONMENTS IN GREECE}

In general terms, phases of Quaternary alluviation in the Voidomatis basin would appear to conform to Vita-Finzi's (1969) Mediterranean valley model of "Older Fill" and "Younger Fill" with evidence of two major alluvial units, onc dated to the end of the last glaciation and the second to the last millennium. Our morpho- and lithostratigraphic investigations, allied with 


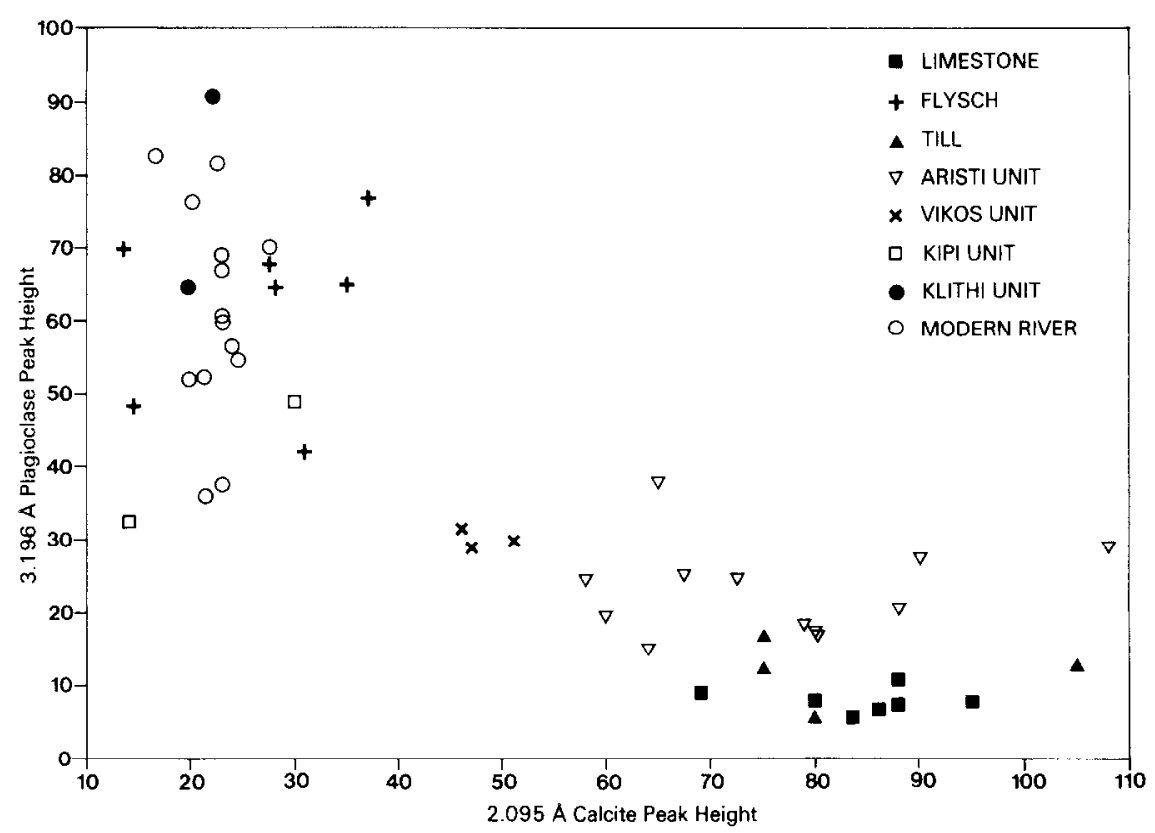

FIG. 5. Mineralogical composition of the fine sediment fraction $(<63 \mu \mathrm{m})$ in Voidomatis Quaternary units as shown by XRD analyses.

radiometric dating, however, have demonstrated that terraced alluvial deposits of late Quaternary age in the Voidomatis that would have been previously classified as "Older Fill" and "Younger Fill" are themselves multiple units.

The Late Würmian coarse-grained Aristi and Vikos alluvial units developed in response to valley glaciation and subsequent deglaciation in the Tsepelovon district (Fig. 1) within the headwaters of Voidomatis. The Aristi unit appears to have been deposited under full-glacial conditions sometime between ca. 28,200 and $24,300 \mathrm{yr}$ B.P. The maximum extent of Late Würmian glaciers in this part of the western Pindus correlates with an unnamed stade at Tenaghi Philippon, northeast Greece, identified by Wijmstra (1969), and dated to between 30,000 and $24,000 \mathrm{yr}$ B.P. On palynological grounds, this represents the most severe climatic episode during the Würm in northern Greece. The lithological homogeneity (Figs. 3 and 5) of the Aristi terrace sediments also suggests that under full-glacial conditions sediment and runoff were gener- ated dominantly from the glaciated part of the catchment. In the lower-lying flysch basins upstream of Kipi and Tsepelovon (Fig. 1), cold and probably very dry conditions during Aristi times would have greatly reduced runoff and sediment delivery from these areas.

The lithological contrasts between the Aristi and the younger Vikos unit (Figs. 3 and 5) show that during deglaciation (post24,300 to ca. 16,600 yr B.P.) considerably more sediment was being delivered to the Voidomatis valley floor from the flysch basin upstream of Kipi, and especially from the ophiolite terrain east of Tsepelovon, than had been the case in full-glacial times. Greater sediment production from slopes in nonglaciated parts of the catchment, together with more frequent and effective sediment transporting channel flows, may have been linked to higher precipitation during this period.

Deglaciation of the Voidomatis and concomitant deposition of the Vikos unit fall within what has been called the Philippi interstade $(20,000-16,000$ yr B.P.) at Tenaghi 


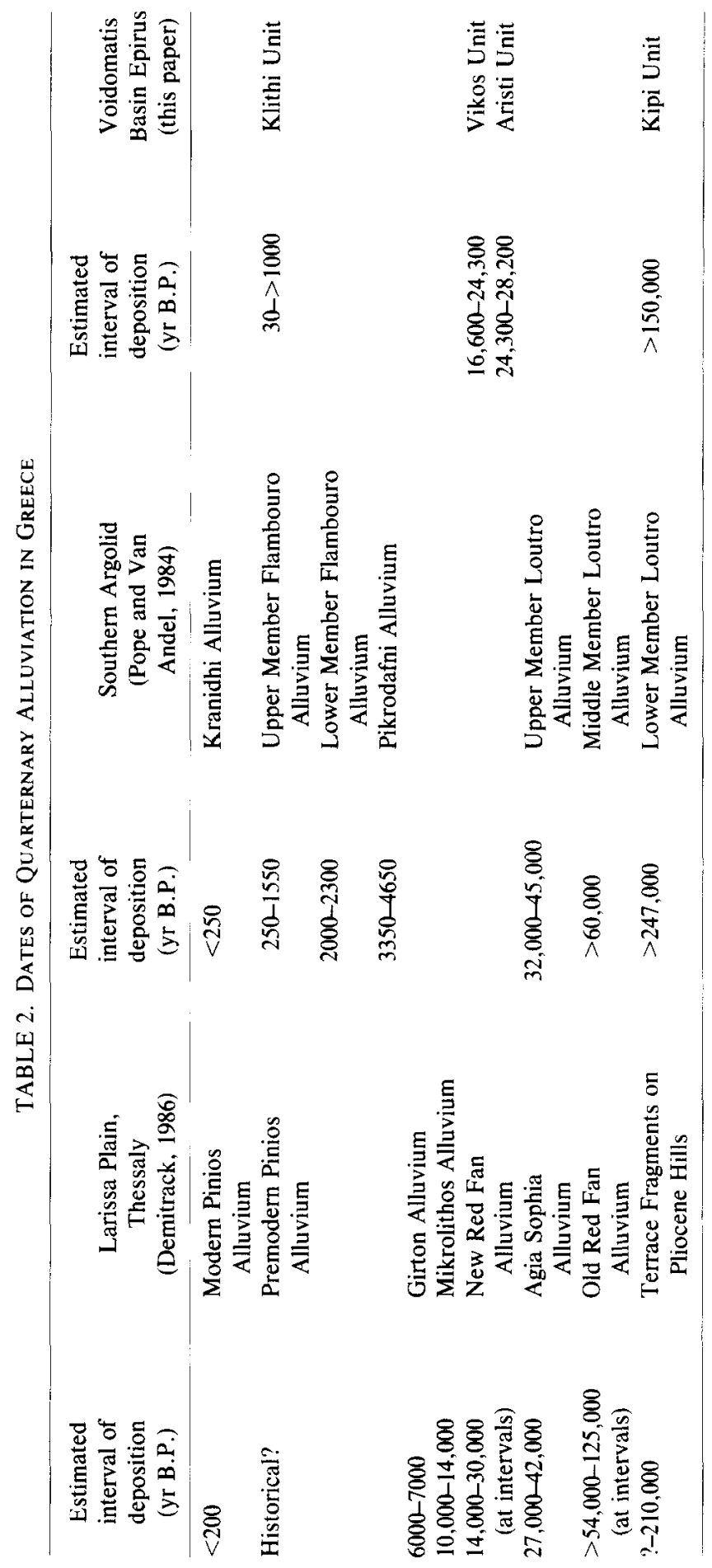


Philippon (Wijmstra, 1969). Toward the end of this phase, about 16,000 yr B.P., archaeological material at the Klithi and Meggalakkos rockshelters shows significantly more-frequent hunting incursions up the lower Vikos gorge by Upper Palaeolithic humans (Bailey et al., 1986). The considerable age gap hetween deposition of the Vikos and Klithi units may indicate progressive incision of the Late Würmian fill, without any significant alluviation for a period of some 15,000 years. Possibly alluviation did occur, and any resulting sediments have been re-eroded. However, there is only evidence for renewed alluviation related to anthropogenically related catchment disturbance in historical times.

A similar pattern has also emerged from studies of Quaternary alluvial sequences in the Larissa Plain, Thessaly (Demitrack, 1986) and southern Argolid (Pope and van Andel, 1984). However, Table 2 shows that there is little or no correlation between dated episodes of Holocene alluviation in these areas. This almost certainly reflects local variations in the timing and pattern of prehistoric and historic landuse, with very late anthropogenically related disturbance of ecosystems in the Voidomatis catchment. Correlation between Pleistocene alluvial units is also generally poor; thus, while a major period of Late Würmian alluviation is evident both in northeast and northwest Greece, deposits of this age are conspicuously absent in southern Argolid. Uncertainties in dating alluvial units older than Late Würmian make comparisons and correlations even more problematic. All three studies thus clearly demonstrate the need for many more detailed investigations of Quaternary alluvial sequences in Greece before episodes of alluviation, both at regional and national scales, can be more firmly dated and causes of valley floor sedimentation be resolved.

\section{CONCLUSIONS}

Geomorphological and sedimentological investigations in the Voidomatis basin, northwest Greece, have identified four Quaternary terraced alluvial fills which radiometric dating has shown range from middle Pleistocene to historic in age. Major periods of alluviation during the late Quaternary were associated with glaciation in the headwaters of the catchment in Late Würmian times and more recently linked to overgrazing on erodible flysch terrains that began sometime before the 11th century AD. The operation of different catchment sediment sources during each major episode of Quaternary alluviation produced lithologically distinctive alluvial fills which can be distinguished and mapped using mineralogical and petrological analysis. The late Quaternary alluvial stratigraphy of the Voidomatis is more complex than the "Older Fill" and "Younger Fill" model outlined by Vita-Finzi (1969). Accordingly, we suggest that these terms no longer be used for alluvial stratigraphic units in the Mediterranean Basin.

\section{ACKNOWLEDGMENTS}

The authors thank Geoff Bailey for inviting them to join the Klithi project, Jane Lewin for her invaluable assistance in the field, and Nick Debenham and Rainer Grün for providing and allowing us to quote unpublished TL and ESR dates. JCW thanks SERC for the provision of a research studentship. Radiocarbon dates were supplied by the Radiocarbon Accelerator Unit at Oxford University whose support is gratefully acknowledged.

\section{REFERENCES}

Bailey, G. N., Carter, P. L., Gamble, C. S., and Higgs, H. P. (1983). Epirus revisited: Seasonality and inter-site variation in the Upper Palaeolithic of north-west Greece. In "Hunter-Gatherer Economy in Prehistory: A European Perspective" (G. N. Bailey, Ed.), pp. 64-79. Cambridge Univ. Press, Cambridge.

Bailey, G. N., Carter, P. L., Gamble, C. S., and Higgs, H. P. (1984). Palaeolithic investigations in Epirus: The results of the first season's excavations at Klithi, 1983. Annual of the British School of Archaeology at Athens 79, 7-22.

Bailey, G. N., Gamble, C. S., Higgs, H. P., Roubet, C., Sturdy, D. S., and Webley, D. P. (1986). Palaeolithic investigations at Klithi: Preliminary results of the 1984-85 field seasons. Annual of the British School of Archaeology at Athens 81, 7-35. 
Baker, V. R., Kochel, R. C., Patton, P. C., and Pickup, G. (1983). Palaeohydrologic analysis of Holocene flood slack-water sediments. In "Modern and Ancient Fluvial Systems" (J. Collinson and J. Lewin, Eds.), pp. 229-239. International Association of Sedimentologists Special Publication 6.

Bintliff, J. L. (1975). Mediterranean alluviation: New evidence from archaeology. Proceedings of the Prehistoric Society 41, 78-84.

Bintliff, J. L. (1977). Natural Environment and Human Settlement in Prehistoric Greece. British Archaeological Reports Supplementary Series 28.

Butzer, K. W. (1980). Holocene alluvial sequences: Problems of dating and correlation. In "Timescales in Geomorphology" (R. A. Cullingford, D. A. Davidson, and J. Lewin, Eds.), pp. 131-142. Wiley, Chichester.

Davidson, D. A. (1980). Erosion in Greece during the first and second millenia BC. In "Timescales in Geomorphology" (R. A. Cullingford, D. A. Davidson, and J. Lewin, Eds.), pp. 143-159. Wiley, Chichester.

Demitrack, A. (1986). "The late Quaternary geologic history of the Larissa Plain, Thessaly, Greece: tectonic, climatic and human impact on the landscape." Unpublished Ph.D. dissertation, Stanford University.

Gilbertson, D. D., Holyoak, D. A., Hunt, C. O., and Paget, F. N. (1983). Palaeoecology of Late Quaternary floodplain deposits in Tuscany: The Feccia valley at Frosini. Archeologia Medievale 10, 340-50.

Gomez, B. (1987). The alluvial terraces and fills of the Lower Vasilikos Valley, in the vicinity of Kalavasos, Cyprus. Transactions of the Institute of British Geographers New Series 12, 345-59.

Harvey, A. M., and Wells, S. G. (1987). Response of
Quaternary fluvial systems to differential epeirogenic uplift: Aguas and Feos river systems, southeast Spain. Geology 15, 689-93.

Jackson, R. G. (1978). Preliminary evaluation of lithofacies models for meandering alluvial streams. In "Fluvial Sedimentology"' (A. D. Miall, Ed.), pp. 543-577. Canadian Society of Petroleum Geologists Memoir 5.

Knox, J. C. (1977). Human impacts on Wisconsin stream channels. Annals of the Association of American Geographers 76, 323-42.

Macklin, M. G., and Lewin, J. (1986). Terraced fills of Pleistocene and Holocene age in the Rheidol valley, Wales. Journal of Quaternary Science 1(1), 21-34.

Pope, K. O., and Van Andel, T. H. (1984). Late Quaternary alluviation and soil formation in the Southern Argolid: Its history, causes and archaeological implications. Journal of Archaeological Science 11, 281-306.

Starkel, L. (1985). Lateglacial and Postglacial history of river valleys in Europe as reflection of climatic changes. Zeitschrift für Gletscherkunde und Glazialgeologie 21, 159-64.

Vita-Finzi, C. (1969). "The Mediterranean Valleys: Geological Changes in Historical Times." Cambridge Univ. Press, Cambridge.

Vita-Finzi, C. (1975). Chronology and implications of Holocene alluvial history of the Mediterranean basin. Biuletyn Geologiczny 19, 137-147.

Wagstaff, J. M. (1981). Buried assumptions: Some problems in the interpretation of the "Younger Fill" raised by recent data from Greece. Journal of Archaeological Science 8, 247-64.

Wijmstra, G. A. (1969). Palynology of the first $30 \mathrm{~m}$ of a $100 \mathrm{~m}$ section in Philippi, Northern Greece. Acta Botonica Neerlandica 18, 511-527. 